\title{
C Dots Derived from Waste of Biomass and Their Photocatalytic Activities
}

\author{
Haryadi ${ }^{\star}$, Muhammad Ridwhan Wira Purnama, and Ari Wibowo \\ Department of Chemical Engineering, Politeknik Negeri Bandung, \\ Jl. Gegerkalong Hilir, Ds. Ciwaruga, Bandung 40559, West Java, Indonesia
}

Received July 17, 2017; Accepted August 15, 2018

\begin{abstract}
Carbon nanodots (CNDs) which are part family of carbon nanoparticles have drawn a lot of attention due to their prominent characters and wide prospective applications. The materials are non-toxic and exhibit fluorescence properties that are potential for application in photocatalysis, optoelectronic, bioimaging and sensors. Various approaches of CNDs synthesis have been investigated by means of a large variety of starting materials and techniques. A green and an effective approach in gaining CNDs from wastes biomass-carbonaceous particles of a dried solid waste of cow manure have been employed by hydrothermal treatment. The CNDs were then attained after carbonaceous particles dissolution step under microwave irradiation. The temperature range of hydrothermal treatment was in between 250 to $300{ }^{\circ} \mathrm{C}$. The formation of $\mathrm{C}=\mathrm{C}, \mathrm{C}-\mathrm{O}$ bonds, and conjugated structures has been observed by FTIR and photoluminescence properties have been identified under $366 \mathrm{~nm}$ of UV irradiation. Furthermore, the morphology of as-synthesized CNDs was investigated by HR-TEM and crystallinity was observed by $X$-Ray Diffraction (XRD). Photocatalytic degradation of synthetic dye solution of methylene blue (MB) in the presence of carbon dots has been investigated under visible light.
\end{abstract}

Keywords: carbon nanodots; photocatalyst; methylene blue

\section{ABSTRAK}

Carbon nanodots (CNDs) yang merupakan bagian dari kelompok nanopartikel karbon, telah menarik banyak perhatian dikarenakan karakter/sifat yang dimiliki dan prospek aplikasinya. Material ini tidak beracun dan memancarkan sifat fluorisensi yang berpotensi untuk diaplikasikan di dalam fotokatalisis, optoelektronik, pencitraanbio (bio-imaging) dan sensor. Berbagai metoda dalam sintesis CNDs telah banyak dilakukan menggunakan berbagai teknik dan bahan baku awal. Pendekatan yang efektif dan ramah lingkungan di dalam memproduksi CNDs dilakukan salah satunya dengan memanfaatkan partikel limbah biomassa kotoran sapi sebagai sumber karbon di dalam percobaan ini melalui proses hidrotermal. karbon nanodots diperoleh setelah proses disolusi partikel karbon melalui radiasi gelombang microwave. Rentang temperature untuk proses hidrotermal diantara $250-300{ }^{\circ} \mathrm{C}$. Ikatan-ikatan $C=C, C-O$ serta struktur konjugasinya diobservasi menggunakan FTIR dan sifat fotoluminisensi diidentifikasi menggunakan radiasi gelombang UV pada panjang gelombang $366 \mathrm{~nm}$. Morfologi dari karbon nanodot (CNDs) diamati menggunakan HRTEM sedangkan sifat kristalinitasnya diukur menggunakan difraksi sinar-X(XRD). Sifat fotokatalitik dari CNDs diuji melalui proses degradasi larutan metilen biru (MB) di bawah radiasi sinar tampak.

Kata Kunci: karbon nanodots; fotokatalis; metilen biru

\section{INTRODUCTION}

Carbon dots (CNDs) was accidentally discovered when single-walled carbon nanotubes have been separated from carbon soot using gel electrophoresis [1]. The study on carbon dots was then developed in the synthesis of fluorescent carbon nanoparticles with a diameter of less than $10 \mathrm{~nm}$ and denoted as CNDs [2]. Carbon dots are recognized as paracrystalline carbon, with the formation of polyaromatic carbon core-shell in angstrom size dimensions and surrounded by amorphous carbon domains. The definite structure, however, is still a matter of discussion.

* Corresponding author.

Email address : haryadi@polban.ac.id
Fluorescent nanomaterials have quantum size effect and the unique effects of nanomaterials as compared with the traditional fluorescent dye, which can overcome many deficiencies of the latter, such as the low stability, weak fluorescence intensity, and fast photobleaching. Therefore, fluorescent nanomaterials have been widely applied in the physical, biological, and chemistry as well as other related fields [2].

Recently, semiconductor quantum dots that are encompassed the type of nanoparticles have great concern because of their unique electronic and luminescent properties [3]. However, these nanoparticles usually contain heavy metals, which are 
generally toxic and therefore limit their further applications in the field of biomedicine [4-6].

The CNDs can be derived from carbon sources. The materials are non-toxic and exhibit the fluorescence properties that are potential for application in photocatalysis, optoelectronic, bioimaging and sensors [7]. There are two strategies in the synthesis of carbon nanoparticles or carbon dots, namely top-down and bottom-up approaches. The bottom-up method is less expensive and low energy consumption making attractive to be developed [2,7]. Several research groups developed hydrophilic CNDs preparation from natural resources including from banana [3], candle soot [4], orange juice [5], waste paper [6] and ground soy beans [8]. Others also established through synthetic routes of citric acid and surface passivating agents using thermal oxidation in air. For the environmental concern, some alternate renewable resources have already been successfully developed as starting materials to prepare carbon dots including soy milk and grass [9-10].

The advent of photocatalytic technology caused the research of photocatalytic technology prosperous, encompassing solar energy, photovoltaic cells, selfcleaning materials, and environmental pollution control and many other related fields. The CNDs can be used for some application, such as photocatalytic material, energy conversion, ion $\mathrm{Fe}^{3+}$ detector, optoelectronic and photocatalytic degradation of methylene blue (MB) [1112].

The greenest method for making CNDs is a simple heating method which develops continuously until now. CNDs have a spherical structure with a diameter of less than $10 \mathrm{~nm}$ which consists of several molecules or nanoclusters atom. On the surface of CNDs, there are ties of $\mathrm{ONH}-\mathrm{COONH}$ in large number which makes easily dispersed in water [7].

The present study demonstrates a rapid synthesis of fluorescent carbon dots developed from dry solid cow manure using thermal processes followed by microwave irradiation in water for the first time. Subsequently, extracted carbon dots were applied for the photocatalytic degradation of MB under visible light irradiation.

\section{EXPERIMENTAL SECTION}

\section{Materials}

All of the chemicals used for the experiment namely ethanol of $96 \% \mathrm{v} / \mathrm{v}, \mathrm{H}_{2} \mathrm{O}_{2} 30 \% \mathrm{v} / \mathrm{v}$, distilled water and MBSigma Aldrich were analytical grade and used without further purification. Solid waste samples of cow manure were collected from local agricultural farm area at Lembang, West Java, Indonesia.

\section{Instrumentation}

Fourier transform infrared (FT-IR) spectra were collected on Shimadzu FT-IR 500 with $\mathrm{KBr}$ disc. Each spectrum was recorded from 4000 to $400 \mathrm{~cm}^{-1}$ using 12 scans at a resolution of $4 \mathrm{~cm}^{-1}$. To acquire crystallinity characteristics of the CNDs, X-ray diffraction (XRD) analysis was carried out using a Pan Analytical PRO diffractometer with a Cu-Ka radiation source. The diffraction patterns were recorded from 5 to $60^{\circ}$. Transmission electron microscope (TEM) and highresolution TEM (HR-TEM) studies for morphological and microstructure characterizations of CNDs were carried out by Hitachi TEM 7700 with operating Voltage at 100 $\mathrm{kV}$. A single UV light source of $366 \mathrm{~nm}$ wavelength was used to observe the photoluminescence characteristics of CNDs dispersed in water. The absorption spectra of CNDs and MB were measured by UV-Vis spectrophotometry (Shimadzu, Japan).

\section{Procedure}

\section{Preparation of CNDs}

First, the semisolid waste of cow manure was dried in the oven for $3-4 \mathrm{~h}$ at temperature $105{ }^{\circ} \mathrm{C}$. Size reduction of the dried solid waste of cow manure was then conducted by the grinding process. Furthermore, the carbonization steps of $1.0 \mathrm{~g}$ of dried sample were conducted between 250 and $300{ }^{\circ} \mathrm{C}$ for $2 \mathrm{~h}$. Finally, the CNDs were obtained by dispersing carbon microparticles in water and then heated through microwave irradiation for 20 min using $180 \mathrm{~W}$ power. The CNDs were then separated from carbon residue by filtration to obtain dispersed CNDs in water as indicated by the brownish color solution.

\section{Photocatalytic experiment}

The photocatalytic activity of CNDs was studied by using MB under visible light of $40 \mathrm{~W}$ tungsten lamp with no UV filter, using volume ratio of 1:20. Observation of MB color degradation by CNDs in water was conducted and analyzed by UV-Vis Spectrophotometer.

\section{RESULT AND DISCUSSION}

Currently, the green synthesis of carbon nanoparticles from organic precursor becomes predominant, particularly for the hydrothermal process. The process was then used to prepare CNDs in the experiment using dried cow manure. In addition, carbonization through hydrothermal process converts biomass into CNDs and also affects surface functionalization leading to being water soluble along with

Haryadi et al. 

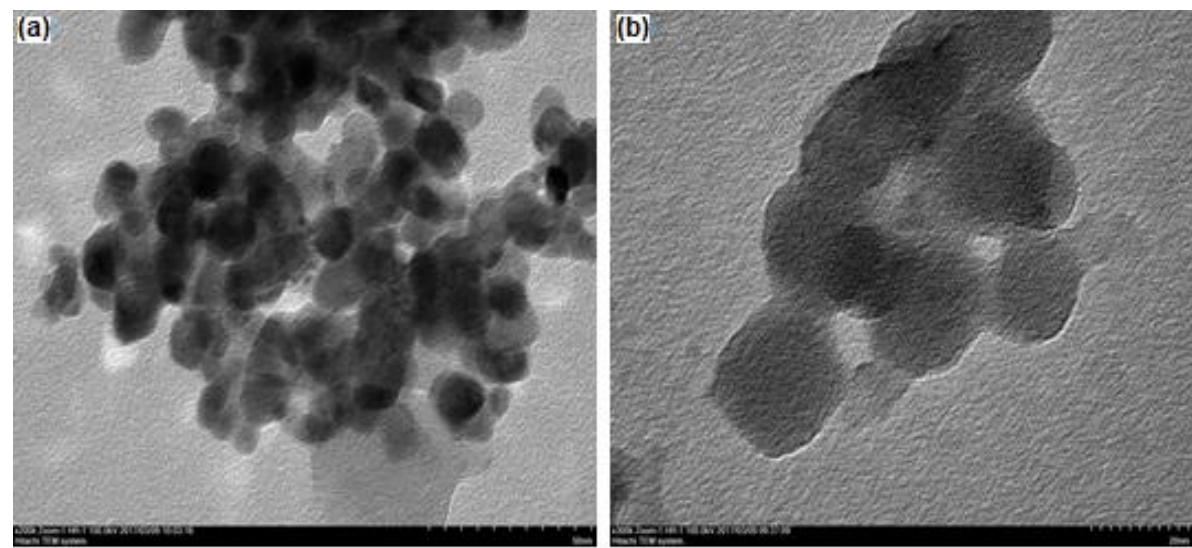

Fig 1. TEM (a) and HRTEM (b) of CNDs

photoluminescent [13]. The possible mechanism for the conversion of the carbonaceous biomass of cow manure to CNDs involves several steps such as dehydration, fragmentation, condensation, aromatization, and carbonization. However, the exact mechanism for the synthesis of CNDs from biomass and other organic mass are still uncertain [14].

\section{Microscopic and Spectroscopic Characterization}

TEM was used to analyze the morphological characterization of CNDs. The TEM images (Fig. 1) clearly illustrate that CNDs are spherical in nature and not uniform in size. The size distribution of the synthesized CNDs has an overall size distribution from 5 to $50 \mathrm{~nm}$ while most of the particles were present in the range 10$15 \mathrm{~nm}$ as shown in Fig. 2. This inhomogeneous size could be attributed to the tunable multicolor fluorescence of the CNDs due to the quantum-confinement effect and characteristics for spherical nano carbons [15].

As indicated in Fig. 1(a), the high-resolution TEM image reveals the spherical size of CNDs. Typical of the crystalline structure of CNDs was appeared by HRTEM analysis and displayed lattice spacing attributed to the (002) surface of graphite (Fig. 1(b)).

The UV-Vis absorption spectrum of CNDs indicates a broad absorption band at $275 \mathrm{~nm}$ assigned to $n-\pi^{*}$ and $\pi-\pi^{*}$ transition of the $-\mathrm{C}=\mathrm{O}$ and conjugated $\mathrm{C}=\mathrm{C}$ bonds and are in agreement with earlier reports for graphitic nano carbons. The aqueous solution of CNDs exhibited bright blue luminescence under UV light irradiation at 366 $\mathrm{nm}$ as demonstrated in Fig. 3(a). CNDs are greatly soluble in water subsequent in a highly dispersed solution as indicated in Fig. 3(b). Furthermore, the solution was also stable for one month and showed no signs of precipitation or aggregation.

FTIR analysis was conducted to analyze the presence of polar functional groups over CNDs surface.

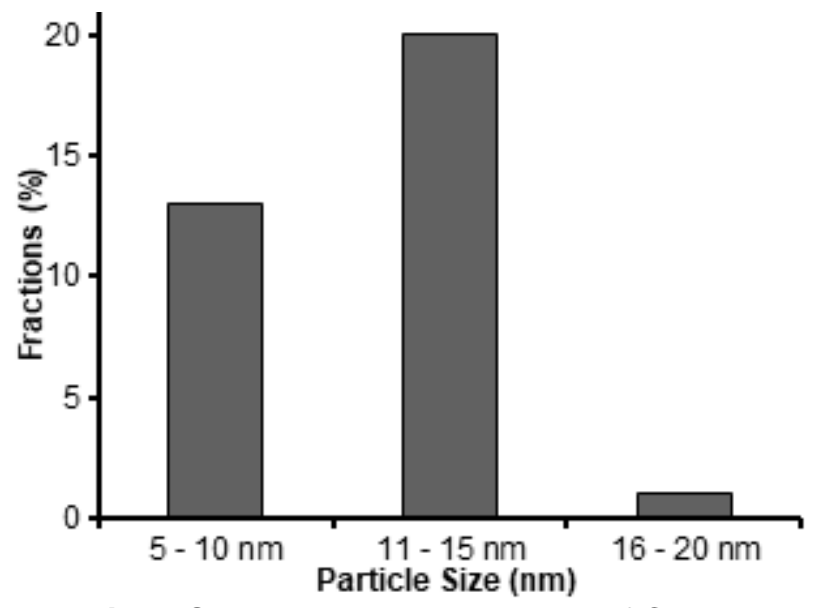

Fig 2. Size distribution histogram of CNDs
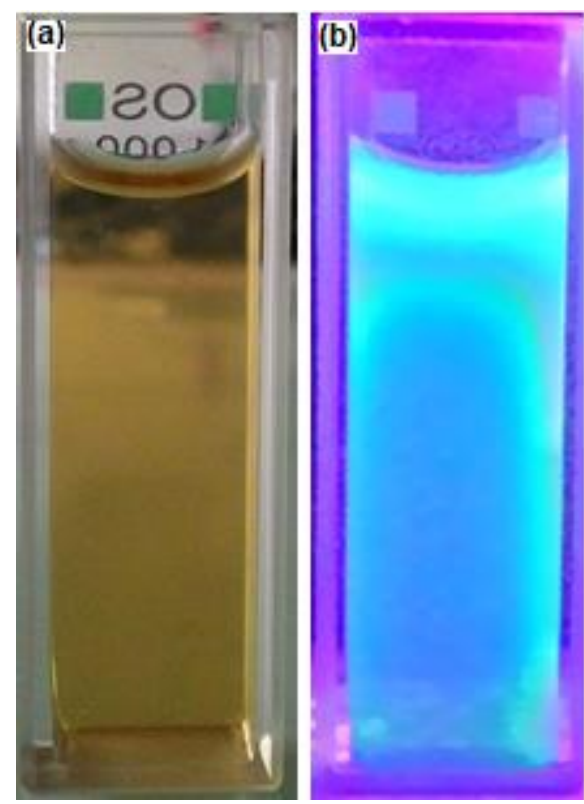

Fig 3. (a) The aqueous solution of CNDs (b) under UV light $366 \mathrm{~nm}$ 


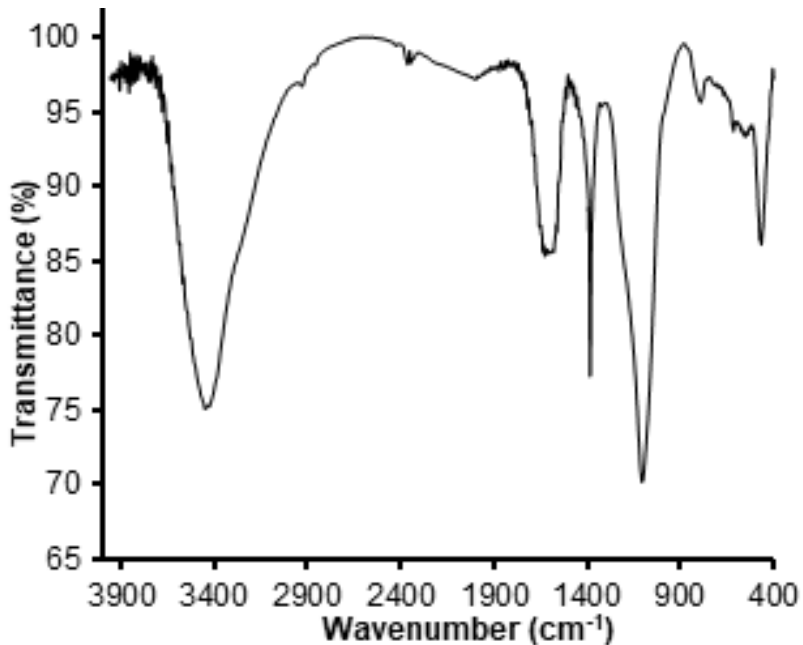

Fig 4. FTIR spectra of CNDs produced at $275^{\circ} \mathrm{C}$

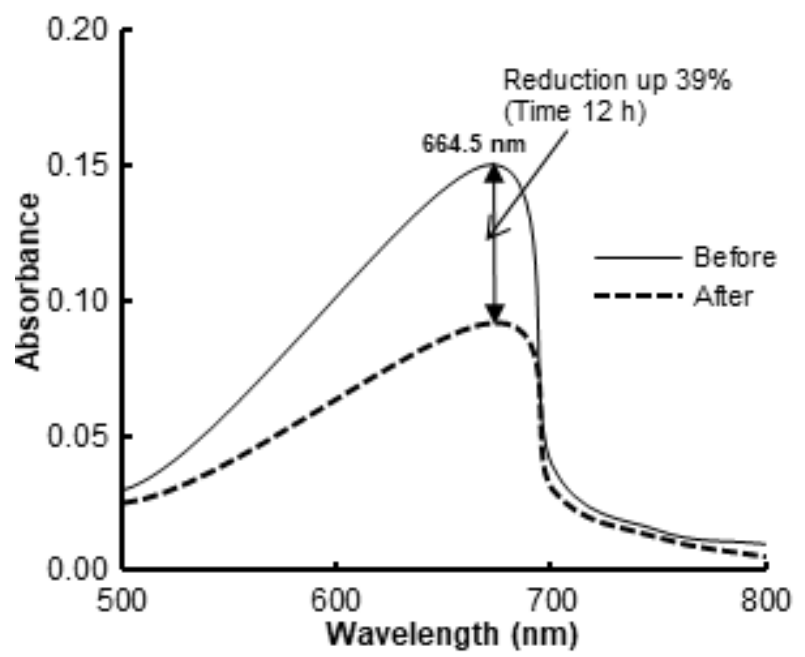

Fig 6. Absorption spectra of MB before and after the photocatalytic process by CNDs

The characteristic absorption bands for $-\mathrm{COOH}$ and $-\mathrm{OH}$ groups are observed as shown in Fig. 4. A broadband at $\sim 3448 \mathrm{~cm}^{-1}$ appears for the $-\mathrm{OH}$ stretching frequency. Two small bands between $2900-2800 \mathrm{~cm}^{-1}$ are ascribed to the $\mathrm{C}-\mathrm{H}$ bonds. A broad peak at $\sim 1600 \mathrm{~cm}^{-1}$ and a sharp peak at $1385 \mathrm{~cm}^{-1}$ are signature for the presence of $-\mathrm{COO}^{-}$and coincided with $\mathrm{C}=\mathrm{C}$. In addition, a peak of $1107 \mathrm{~cm}^{-1}$ could be identified as the $\mathrm{C}-\mathrm{O}$ of graphitic carbons [16]. In addition, a sharp peak at $466 \mathrm{~cm}^{-1}$ appears as a graphite framework. FTIR spectrum reveals the presence of hydrophilic surface functional groups over CNDs surface leading to the excellent water solubility.

The X-ray powder diffraction (XRD) patterns were used to investigate the crystallinity of the synthesized CNDs. XRD pattern of the CNDs displays a slightly broad and high-intensity diffraction peak (Fig. 5) $(2 \theta)$ centered at $24^{\circ}$ owing to graphitic (002) lattice spacing, which arises due to the presence of highly disordered $\left(\mathrm{sp}^{3}\right)$

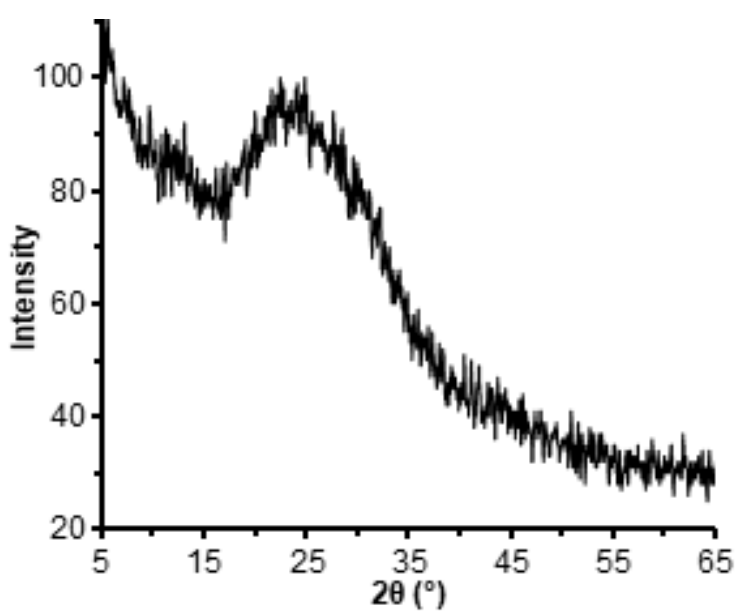

Fig 5. XRD spectra of CNDs

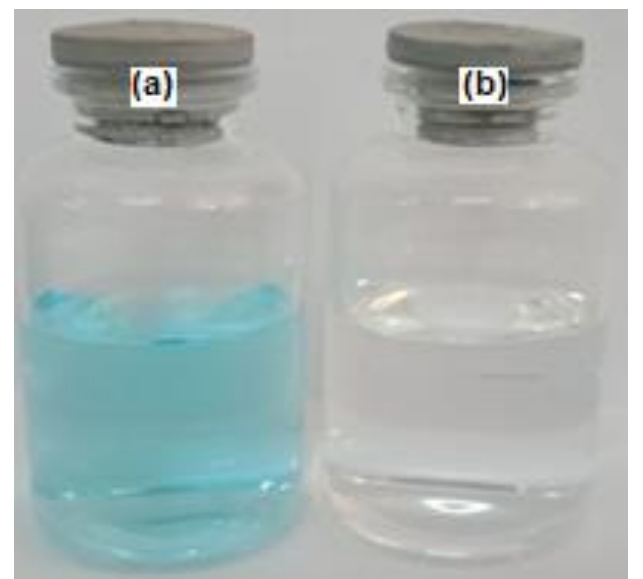

Fig 7. Digital images of photocatalytic degradation of $M B$ by CNDs, (a) before and (b) after degradation under visible light

carbon atoms and is consistent with FTIR and HRTEM results.

\section{Photocatalytic Activity of CNDs}

Photocatalytic degradation of MB was performed in a glass of sample bottle under visible light irradiation using a $40 \mathrm{~W}$ tungsten lamp. Initial concentration for the photocatalytic experiment was taken for $\mathrm{MB}$ and no significant degradation of $\mathrm{MB}$ was observed when exposed to visible light without photocatalyst of CNDs. Further, MB was exposed under the irradiation of visible light in presence of CNDs and substantial change in the absorbance specified the important function of CNDs in the degradation of MB.

Characteristic peak for absorption of $M B$ was observed at $664.5 \mathrm{~nm}$. Upon irradiation, both the blue color of the MB solution and absorption peak intensity 
were decreased is shown in Fig. 6. The CNDs were dispersed homogeneously to the entire solution of the MB providing to straightforwardly for the degradation process. The photocatalytic activities of CNDs from the dried solid waste of cow manure in a solution of MB were revealed in Fig. 7. The results indicated that effective degradation for MB by using CNDs for $12 \mathrm{~h}$ was $39 \%$ for the volume ratio of $1: 20$

Generally, most of the dyes contain azo bonds that are nitrogen double bonds $(-\mathrm{N}=\mathrm{N}-)$ in the structure which are the most active bonds. These bonds could be cleaved either by an oxidation process using hydroxyl radicals or reduced by electrons leading to the subsequent decolorization of the synthetic dyes [17]. It was presumed that CNDs provide a medium that produces free radicals of superoxide and hydroxyl radicals which then enables to decompose the synthetic azo dye compounds [18]. Moreover, the interval of photocatalytic activity under visible light irradiation greatly affects the degradation process.

\section{CONCLUSION}

The water-soluble CNDs were produced using the hydrothermal process of a dried solid waste of cow manure. The simple and green synthetic bottom-up approach for CNDs resulted from the dried solid waste of cow manure carbonization process and extracted by water-assisted microwave irradiation were presented. As synthesized CNDs have the nearly spherical morphology and narrow size distribution with most of the particle size in the range of $10-15 \mathrm{~nm}$. The CNDs show easily dispersed in water which confirms of having hydrophilic functional groups as observed by infrared spectroscopy. Besides, they also exhibit photoluminescence properties as designated from the UV absorption spectrum. The photocatalytic activity of CNDs has been demonstrated by the degradation performance of $\mathrm{MB}$ under the visible light condition and reduced up to $40 \%$ after $12 \mathrm{~h}$.

\section{ACKNOWLEDGEMENT}

This work was financially supported by Politeknik Negeri Bandung Indonesia under the scheme of Applied Research Grant 2016. Authors are also thankful to the Department of Chemical Engineering, Politeknik Negeri Bandung for providing all facilities.

\section{REFERENCES}

[1] Xu, X., Ray, R., Gu, Y., Ploehn, H.J., Geaheart, L., Raker, K., and Scrivens, W.A., 2004, Electrophoretic analysis and purification of fluorescent single-walled carbon nanotube fragments, J. Am. Chem. Soc., 126 (40), 12736-12737.
[2] Li, H., Kang, Z., Liu, Y., and Lee, S.T., 2012, Carbon nanodots: Synthesis, properties and applications, $J$. Mater. Chem., 22 (46), 24230-24253.

[3] Sahu, S., Behera, B., Maiti, T.K., and Mohapatra, S., 2012, Simple one-step synthesis of highly luminescent carbon dots from orange juice: Application as excellent bio-imaging agents, Chem. Commun., 48 (70), 8835-8837.

[4] Ray, S.C, Saha, A., Jana, N.R., and Sarkar, R., 2009, Fluorescent carbon nanoparticles: synthesis, characterization, and bioimaging application, $J$. Phys. Chem. C, 113 (43), 18546-18551.

[5] De, B., and Karak, N., 2013, A green and facile approach for the synthesis of water-soluble fluorescent carbon dots from banana juice, RSC Adv., 3 (22), 8286-8290.

[6] De, B., and Karak, N., 2013, A green and facile approach for the synthesis of water soluble fluorescent carbon dots from banana juice, RSC Adv., 3 (22), 8286-8290.

[7] Zuo, J., Jiang, T., Zhao, X., Xiong, X., Xiao, S., and Zhu, Z., 2015, Preparation and application of fluorescent carbon dots, J. Nanomater., 2015, 787862.

[8] Lu, Y.C., Chen, J., Wang, A.J., Bao, N., Feng, J.J., Wang, W., and Shao, L., 2015, Facile synthesis of oxygen and sulfur co-doped graphitic carbon nitride fluorescent quantum dots and their application for mercury(II) detection and bioimaging, J. Mater. Chem. C, 3 (1), 73-78.

[9] Srivastava, S., and Gajbhiye, N.S., 2011, Carbogenic nanodots: Photoluminescence and room-temperature ChemPhysChem, 12 (14), 2624-2632.

[10] Krysmann, M.J., Kelarakis, A., Dallas, P., and Giannelis, E.P., 2012, Formation mechanism of carbogenic nanoparticles with dual photoluminescence emission, J. Am. Chem. Soc., 134 (2), 747-750.

[11] Baker, S.N., and Baker, G.A., 2010, Luminescent carbon nanodots: Emergent nano lights, Angew. Chem. Int. Ed., 99, 6726-6744.

[12] Aji, M.P., Wiguna, P.A., Suciningtyas, S.A., Susanto, Rosita, N., and Sulhadi, 2016, Carbon nanodots from frying oil as a catalyst for photocatalytic degradation of methylene blue assisted solar light irradiation, Am. J. Appl. Sci., 13 (4), 432-438.

[13] Hu, B., Wang, K., Wu, L., Yu, S.H., Antonietti, M., and Titirici, M.M., 2010, Engineering carbon materials from the hydrothermal carbonization process of biomass, Adv. Mater., 22 (7), 813-828.

[14] Yin, B., Deng, J., Peng, X., Long, Q., Zhao, J., Lu, Q., Chen, Q., Li, H., Tang, H., Zhang, Y., and Yao, S., 2013, Green synthesis of carbon dots with 
down- and up-conversion fluorescent properties for sensitive detection of hypochlorite with a dualreadout assay, Analyst, 138 (21), 6551-6557.

[15] Georgakilas, V., Perman, J.A., Tucek, J., and Zboril, R., 2015, Broad family of carbon nanoallotropes: Classification, chemistry, and applications of fullerenes, carbon dots, nanotubes, graphene, nanodiamonds, and combined superstructures, Chem. Rev., 115 (11), 4744-4822.

[16] Tripathi, K.M., Tyagi, A., Ashfaq, M., and Gupta, R.K., 2106, Temperature-dependent, shape variant synthesis of photoluminescent and biocompatible carbon nanostructures from almond husk for applications in dye removal, RSC Adv., 6 (35), 29545-29553.

[17] Fragoso, C.T., Battisti, R., Miranda, C., and de Jesus, P.C., 2009, Kinetic of the degradation of C.I. Food Yellow 3 and C.I. Food Yellow 4 azo dyes by the oxidation with hydrogen peroxide, J. Mol. Catal. A: Chem., 301 (1-2), 93-97.

[18] Park, S.Y., Lee, H.U., Park, E.S., Lee, S.C., Lee, J.W., Jeong, S.W., Kim, C.H., Lee, Y.C., Huh, Y.S., and Lee, J., 2014, Photoluminescent green carbon nanodots from food-waste-derived sources: Largescale synthesis, properties, and biomedical applications, ACS Appl. Mater. Interfaces, 6 (5), 3365-3370. 